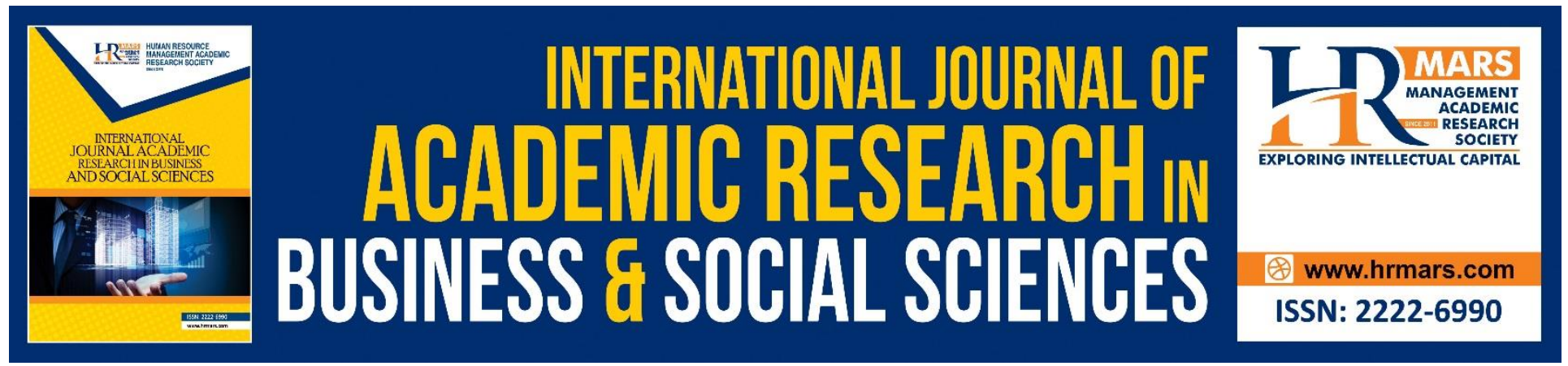

\title{
The Relationship between CSR, Corporate Image and Customer Satisfaction on Purchase Intention: A Review of Literature
}

\author{
Ahmad Shukri Yazid, Ibrahim Mohammad Mkheimer, Norfazilah Rashid, Puspa \\ Liza Ghazali, Fauzilah Salleh, Nadiah Abdul Hamid, \\ Zarinah Abdul Rasit, Razana Juhaida Johari
}

To Link this Article: http://dx.doi.org/10.6007/IJARBSS/v8-i11/5207 DOI: 10.6007/IJARBSS/v8-i11/5207

Received: 18 Oct 2018, Revised: 21 Nov 2018, Accepted: 02 Dec 2018

Published Online: 04 Dec 2018

In-Text Citation: (Yazid et al., 2018)

To Cite this Article: Yazid, A. S., Mkheimer, I. M., Rashid, N., Ghazali, P. L., Salleh, F., Hamid, N. A., ... Johari, R. J. (2018). The Relationship between CSR, Corporate Image and Customer Satisfaction on Purchase Intention: A Review of Literature. International Journal of Academic Research in Business and Social Sciences, 8(11), 1498-1507.

\section{Copyright: (c) 2018 The Author(s)}

Published by Human Resource Management Academic Research Society (www.hrmars.com)

This article is published under the Creative Commons Attribution (CC BY 4.0) license. Anyone may reproduce, distribute, translate and create derivative works of this article (for both commercial and non-commercial purposes), subject to full attribution to the original publication and authors. The full terms of this license may be seen at: $\underline{\text { http://creativecommons.org/licences/by/4.0/legalcode }}$

Vol. 8, No. 11, 2018, Pg. 1498 - 1507

Full Terms \& Conditions of access and use can be found at http://hrmars.com/index.php/pages/detail/publication-ethics 


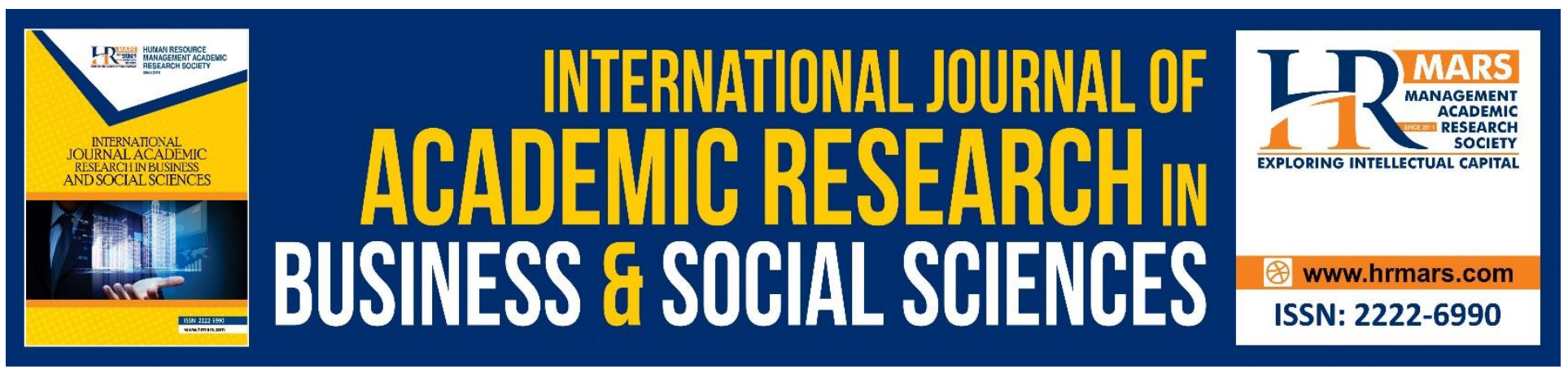

\title{
The Relationship between CSR, Corporate Image and Customer Satisfaction on Purchase Intention: A Review of Literature
}

\author{
${ }^{1}$ Ahmad Shukri Yazid, ${ }^{2}$ Ibrahim Mohammad Mkheimer*, ${ }^{3}$ Norfazilah \\ Rashid, ${ }^{4}$ Puspa Liza Ghazali, ${ }^{5}$ Fauzilah Salleh, ${ }^{6}$ Nadiah Abdul \\ Hamid, ${ }^{7}$ Zarinah Abdul Rasit, Razana Juhaida Johari ${ }^{8}$ \\ 1,3,4,5 Faculty of Economics and Management Sciences, Universiti Sultan Zainal Abidin, Terengganu, \\ Malaysia \\ ${ }^{6,7,8}$ Faculty of Accoutancy, Universiti Teknologi MARA, 42300 Bandar Puncak Alam, Malaysia \\ ${ }^{2}$ Universiti Malaya, 50603 Kuala Lumpur, Malaysia \\ Corresponding Author: nikmfadzilah@unisza.edu.my
}

\begin{abstract}
Although corporate social responsibility (CSR), corporate image, customer satisfaction and purchase intention have occupied a lot of researches' interest in the business field, not much is known about their interrelationships. The paper aims to explore the association between the CSR, corporate image, and purchase intention with focus on the mediating effect of customer satisfaction. The paper provides a conceptual insight into association among CSR and corporate image and their impacts on purchase intention via customer satisfaction. The theoretical contribution for the study is to develop a model that contains CSR, corporate image, customer satisfaction and purchase intention in path relationship. The study as well tries to investigate the mediating role of customer satisfaction on purchase intention for two independent variables: corporate social responsibility and corporate image.
\end{abstract}

Keywords: Corporate Social Responsibility (CSR), Corporate Image, Customer Satisfaction And Purchase Intention

\section{INTRODUCTION}

CSR has obtained large amount of concern in a few past decades, governments starts to act laws and regulations for corporate responsibilities toward society and environment, and the customers have become more informed about the social responsibilities. Companies now utilize CSR practices as promotion means to obtain positive image and maximize their profits. Despite of the CSR applications have been common for decades in the developed countries, the concept is still not mature in the developing countries. This study aims to review the relationship between CSR and corporate image 
and their influence on purchase intention with mediating effect of customer satisfaction in the Jordan telecommunication context. The telecommunication sector has high value and critical positioning within vital economic sectors. It has contributed more than 80,000 direct and indirect jobs, and it exports its products to more than 30 destinations over the world. The formal figures showed that the base of subscriptions to cellular service reached 12.3 million subscribers with a penetration rate of $147 \%$ of the population, while the percentage of Internet penetration reached $73 \%$ of the population with the number of users is about 6.2 million. In terms of figures, this sector testifies quick growth from 2000 to 2013, with official numbers revealed that the revenues increased from $\$ 623$ million in 2000 to $\$ 2.3$ billion in 2013 (Ismail et al., 2016).

\section{THE RELATIONSHIP BETWEEN CSR AND CUSTOMER SATISFACTION}

In the business literature, customer satisfaction has been classified as an essential part of organizational strategies and a prime stimulus of company long-term sustainability and market share. Thus, it is logically that CSR is strongly connected to customer satisfaction. CSR looks to be a leading point connecting with customer satisfaction. It is known that good companys' history of CSR relate to higher degree of customer satisfaction. Many researchers agreed that CSR can positively promote good reputation (Alfadhli, Rashid, \& Yaakub, 2018). CSR initiatives may lead to better customer satisfaction. A few researchers have suggested the concept of "generalized customer" to indicate people from several parties which organizations should take into consideration. Generalized customer is more likely to become pleased with products or services which socially responsible organizations have offered (Alfadhli et al., 2018). Also, a rich history of CSR intiatives can create a helpful environment which favorably uphold consumers appraisal and conducts into the company (Usop et al., 2018). Moreover, involving in CSR may permit companies to grasp their potential customers greater, hence develop their customers' satisfaction (S. A. Ismail et al., 2016). Analyzing the influence of CSR on customer satisfaction has gained some of studies' interests which showed that CSR has favorable and essential impact on customer satisfaction (Norliana, Fakhrul Anwar, Wan Norhayate, Norfadzilah, \& Asyraf, 2018). Company social actions can directly affect customer needs through great level of goodwill (Norliana et al., 2018). Charitable sides, for instance, donation or philanthropic efforts, supporting CSR has positive linked with customer satisfaction (Zainol et al., 2018). On the other hand some results (Adnan \& Bakar, 2009) showed that sponsorship and charitable conducts catergorized very little amongst customer when they intent to purchase. Therefore, many researches showed that the humanitarian natured actions and society development programs achieved by companies are significantly connected with customer satisfaction (Sambharya, 2011).

\section{THE RELATIONSHIP BETWEEN CORPORATE IMAGE AND CUSTOMER SATISFACTION}

Corporate image has been evaluated as a significant antecedent of customer satisfaction. In business arena, some researches have exposed crucial part for corporate image in consumption behaviors for customers in products or services enterprises (Kraft, Lee, \& Lopatta, 2014). Corporate image is considered as one of the most important element in the process of building up and preserving satisfaction towards an organizations (Zainol et al., 2018). The passionate constituents related to psychological contexts manifested by conducts and emotions towards the firms' products 
and service whilst functional element is related to materialistic sides of product and service. A study has discussed that corporate image is a behavior which is mainly related to satisfaction for customers due to its functional ingredients (Kurniasih et al., 2018). Corporate image is significantly associated with customer satisfaction in various industries like education and telecommunication in many states (M. Ismail et al., 2018). The same results are true for food industry and postal service in Denmark (Sabiu et al., 2018). A study debates that corporate image is an essential column for the organizations to broaden their returns, to survive in a competition, winning new customers and expanding their market values (Salleh, Ibrahim, et al., 2018). Another review has proved positive effect of corporate image on customers satisfaction and loyalty (Ayers, Jiang, \& Laplante, 2009). A perfect corporate image for good quality means additional customers, lower dissatisfied customers may positively reproduce profit which make the organizations on a good competitive positioning. In another studies indicate that good corporate image influence cuatomer satisfaction (Bryant-Kutcher, Guenther, \& Jackson, 2012).

\section{THE RELATIONSHIP BETWEEN CSR AND PURCHASE INTENTION}

Professionals emphasize the association of CSR with customers buying process, due to the fact that social responsibility is becoming popular in global economy. Based on literature, the purchase intention is also one of the rife drive displayed from verbal communication (Otusanya, 2011). Customer attitudes become appropriate or not based on negative or positive feedback of customer experience (Ball \& Shivakumar, 2008). Customer's perception of CSR has a direct effect on purchase intention where more favorable perception of CSR generates higher purchase intention (Johari, Rashid, \& Yazid, 2018). Customers are more willing to buy products from companies which are engaged in social programs. A research has contributed toward understanding the effect of a company's socially responsible activities on consumers' attitudes and purchase intentions toward a company. Consumers who informed to CSR reports showed positive attitudes and good purchase intentions toward the company (Salleh, Ibrahim, et al., 2018). The number of customers who made their purchase decisions basis on organizations CSR plans are increasing by observing the company's CSR practices or ethical behaviors. Scholar has showed that importance of CSR is increasing in consumer buying process. It is extremely important to assert that CSR is becoming more vital in emerging markets. They also noted that customer expectations and requirements have been increased. Customer expect from the companies to be a citizen and a part of their local community (Ayers et al., 2009). When customers point out that the company has a rich CSR history, they may tend to reward the company for instance, buying products frequently. Once customers discover that the company has bad evidence of CSR actions, they would behave unfavourably like boycott (S. A. Ismail et al., 2016).

\section{THE RELATIONSHIP BETWEEN CORPORATE IMAGE AND PURCHASE INTENTION}

The corporate image plays major role in forming customer purchasing behaviour. Corporates began to concentrate on building its image. Establishing good corporate image may influence customers' evaluation to its product which may lead to preference product and enhance purchase intention. A study investigated the possible impact of corporate social responsibility on corporate image and purchase intentions for customers, it provided guidelines for organizations policy makers 
who involved in establishing competitive advantage also maintain sustainable boom in the business (Noor, Norhayate, Rashid, \& Asyraf, 2018). The study concluded that corporation image also affects positively on development of purchase intentions for consumers (S. A. Ismail et al., 2016). A study explored the relationships among corporate social responsibility, service quality, corporate image, and purchase intentions. Corporate image was the mediating construct in exploring how corporate social responsibility and service quality affect the purchase intentions of consumers. The study found that corporate image has a positive impact on purchase intention (Rashid, Fara, et al., 2018). Corporate image was considered as one of the essential strategical resources which grant organizations with enriched base to establish steady and long-term grown competitive advantage amongst competitors in the business (Rashid, Muhmad, et al., 2018). Multiple regression analysis indicated the corporate image mediates positively and strengthen the relationship between the perceived electronic word of mouth (eWOM) and purchase intention (Salleh, Noor, et al., 2018). Furthermore, the study has concluded that understandable comments about the university possibly will make a powerful impact on schools students' purchase intention.

\section{THE RELATIONSHIP BETWEEN CUSTOMER SATISFACTION AND PURCHASE INTENTION}

Customer satisfaction may create posterior responses for instance repurchase and good word-of-mouth interactions. Many literatures showed a direct association between customer satisfaction and purchase intention (Usop et al., 2018). As well, some reviewers have suggested that the linkage among customer satisfaction and behavior intention is not strong, (Salleh, Noor, et al., 2018). Furthermore, they conclude that pleasant customers are not importantly sincere customers, meanwhile, a research conducted (Rashid, Fara, et al., 2018) referred unimportant connection among satisfaction and purchase intention. Customer satisfaction is an essential influencial factor in repeated purchasing behaviors, and discussed generally as a variable in the business literature. A study supposed that if the evaluation after purchasing is greater than formerly expected, the product or service will be regarded satisfactory, conversely if it is worse than what customer anticipate then it will be regarded unsatisfactory (S. A. Ismail et al., 2016). Satisfaction is not only the main motivation of customers' purchasing intention, but also to establish and retain a loyal foundation of long relationship customers (Noor et al., 2018). Many studies have revealed that satisfaction aids in creating loyalty, forming good word of mouth and increasing purchase intentions (Rashid, Fara, et al., 2018). Hence, customer satisfaction is not a modern term, many studies' efforts have been conducted to grasp its antecedents and outcomes. Along with customer satisfaction, it is also substantial to comprehend purchase intention since customers' behavior can often be forecasted by their intents. A researcher refered that purchase intent is one aspect of behavior intention (Mahmod et al., 2018). To investigate customer's behavioural manners, purchase intent has been utilized to forecast behavior because of its association to real behavior, and the connection has been tested in several industries (M. Ismail et al., 2018). As well, a wide collection of literature is available on behavior intents in some environments (Kurniasih et al., 2018). As other demonstrated, the familiar behavioural aspects that have been investigated in the literature are repeat intentions or purchase behaviour, tendency to offer WOM, price acceptance, and tendency to do extra purchases from the same company (Zainol et al., 2018). 
INTERNATIONAL JOURNAL OF ACADEMIC RESEARCH IN BUSINESS AND SOCIAL SCIENCES

Vol. 8, No. 11, Nov, 2018, E-ISSN: 2222-6990 @ 2018 HRMARS

\section{THE MEDIATING EFFECT OF CUSTOMER SATISFACTION BETWEEN CSR AND PURCHASE INTENTION}

A primary discussion with customer satisfaction have been revealed helpful construct with CSR practices to form positive customer behavior. Some of reviews have been tested the impact of CSR on purchase intentions, but the outcomes are inconsistent with some researches which propose positive impact of CSR on customer attitude and thus on purchase intention. While others showing no impact of CSR on customer purchase intention (Hamid et al., 2018). A study in the field of CSR and customer behavior applied a framework that integrate CSR, customer awareness, product quality and customer satisfaction to gauge their impacts on purchase intention for customers and consequently on consumers' loyalty. Also they gauge the level of customer knowledge relating to CSR actions, customer satisfaction emerging from quality of the services or goods and then their impacts on customer purchase intentions (Sabiu et al., 2018). The study showed no effect of CSR works on customer purchase intentions, also satisfaction has no effect on purchase intention in cellular industry of Pakistan (Zain, Abdullah, \& Rashid, 2018). However, customer should be informed of CSR activities to gain a favorable impact on purchase intentions (Johari, Tarmizi, Mohd, \& Rashid, 2018), but customer always note it hard to get information about the CSR reports of companies. There is a continuous proof referring that the association between a CSR works and consumers' response is indirect (Salleh, Ibrahim, et al., 2018). Therefore, this study aimed to enhance contribution in this scope by incorporating certain mediators like customer satisfaction on the relationship between CSR and purchase intention (Ayers et al., 2009). Since customer satisfaction was a substantial condition for customer to pay premium price for CSR, the study defend the precaution management of CSR to handle customers' anticipation of CSR (Adnan \& Bakar, 2009). Despite of there is a little study that specifically investigate the association between customer satisfaction and customer purchasing intentioncand CSR, Yuen and his colleagues proposed that a satisfied customer may be ready to pay more as a result of a company's service performance, but not necessarily for company socially actions. This indicates that the effect of customer satisfaction on purchasing for CSR could be mediated by other construct which have not been regarding through present studies.

\section{THE MEDIATING EFFECT OF CUSTOMER SATISFACTION ON THE RELATIONSHIP BETWEEN CORPORATE IMAGE AND PURCHASE INTENTION}

The concept of the corporate image construct has originated since the past two decades. A study have investigated if there is a significant association between corporate image and customer loyalty. the study stated that a positive corporate image may give a great sign of customer satisfaction into a company's products or services (Zain et al., 2018). However, (M. Ismail et al., 2018) proposed the significane of corporate image with the process of decision-making and, consequently, to purchase. It is noted that developing corporate image is favorably associated with growing intents to repurchase. Others have examined correlationships among price recognition, behavioral intention, passenger satisfaction, perceived value, corporate image and service quality into Korean airlines sector (Afthanorhan, Awang, Rashid, Foziah, \& Ghazali, 2019). Their study noted that the airline sector with a good corporate image can capture more customers (Ayers et al., 2009). According to relevant reviews, firms with a great image will earn more customer satisfaction and customer purchase intention (Johari, Rashid, et al., 2018). They noted that frequent purchased services, corporate image instead of customer satisfaction is the fundamental indicator of loyalty (Norliana et 
al., 2018). Some marketers have noted that corporate image may effect the shoppers' buying decision, like good corporate image encouraging purchasing from particular company by facilitating decision procedures (Rashid, Muhmad, et al., 2018). In this study, corporate image has become a topic of attitudes with respect to customer satisfaction and behaviour (Rashid, Fara, et al., 2018). A general claim is that a satisfactory corporate image will gain a proper impact on customers' conducts into the brand, like the opportunity to ask high prices, buyers with high sincere, and more suitable word-of-mouth (Ali, Abdullah, \& Rashid, 2018). Despite of these researches have importantly contributed to the understanding of corporate image in the context of multiple sectors either services or products, it is surprised to know that little empirical studies have been conducted to examine the mediating effect of corporate image with customer satisfaction and purchase intention correlations.

\section{CONCLUSION}

This study has demonstrated the importance positive relationship between CSR, corporate image, customer satisfaction and purchase intention in the context of Jordanian telecommunication sector. Global rapid overall changes have considerable concern in the multiple countries. Recently Jordanian customers have given much care towards CSR practices while these practices may enhance corporate image and earn customer satisfaction which may increase their purchases of company's' products or services. Therefore, while exploring for related studies, many of them examine the relationship between CSR, corporate image, customer satisfaction and purchase intention. A few of the past studies revealed a significant and positive relationship between them and recommended to expand the study through by choosing different population or industry or even country. A major contribution of this study is to study the relationship between certain construct like customer satisfaction, CSR and purchase intention in developing countries.

\section{References}

Adnan, M. A., \& Bakar, N. B. A. (2009). Accounting treatment for corporate zakat: a critical review. International Journal of Islamic and Middle Eastern Finance and Management, 2(1), 32-45. http://doi.org/10.1108/17538390910946258

Afthanorhan, A., Awang, Z., Rashid, N., Foziah, H., \& Ghazali, P. L. (2019). Assessing the effects of service quality on customer satisfaction. Management Science Letters, 9(1), 13-24. http://doi.org/10.5267/j.msl.2018.11.004

Alfadhli, M. I., Rashid, N., \& Yaakub, N. (2018). The Impact of Internal Audit and its Quality on Sales in Economic Institutions : A Case Study ( Al-Ahlia Cement Company - Libya ) The Impact of Internal Audit and its Quality on Sales in Economic Institutions : A Case Study ( Al-Ahlia Cement Company - Lib. International Journal of Academic Research in Business and Social Sciences, 8(8), 50-65. http://doi.org/10.6007/IJARBSS/v8-i8/4434

Ali, A. R., Abdullah, B., \& Rashid, N. (2018). An Error Analysis Approach in Identifying the Patterns of Mistakes in Jawi Spelling An Error Analysis Approach in Identifying the Patterns of Mistakes in Jawi Spelling. International Journal of Academic Research in Business and Social Sciences, 8(11), 1222-1231. http://doi.org/10.6007/IJARBSS/v8-i11/5164

Ayers, B. C., Jiang, J. (Xuefeng), \& Laplante, S. K. (2009). Taxable Income as a Performance Measure: 
INTERNATIONAL JOURNAL OF ACADEMIC RESEARCH IN BUSINESS AND SOCIAL SCIENCES

Vol. 8, No. 11, Nov, 2018, E-ISSN: 2222-6990 @ 2018 HRMARS

The Effects of Tax Planning and Earnings Quality. Contemporary Accounting Research, 26(1), 15-54. http://doi.org/10.1506/car.26.1.1

Ball, R., \& Shivakumar, L. (2008). Earnings quality at initial public offerings. Journal of Accounting and Economics, 45(2-3), 324-349. http://doi.org/10.1016/j.jacceco.2007.12.001

Bryant-Kutcher, L. a., Guenther, D. a., \& Jackson, M. (2012). How Do Cross-Country Differences in Corporate Tax Rates Affect Firm Value? The Journal of the American Taxation Association, 34(2), 1-17. http://doi.org/10.2308/atax-10207

Hamid, N. A., Aisyah, H., Taib, M., Noor, R., Yaacob, Z., Shamsuddin, R., ... Afthanorhan, A. (2018). The Effect of Tax Reforms on Tax Agents ' Job Burnout in Malaysia The Effect of Tax Reforms on Tax Agents ' Job Burnout in Malaysia. International Journal of Academic Research in Business and Social Sciences, 8(12), 547-560. http://doi.org/10.6007/IJARBSS/v8-i12/5054

Ismail, M., Zainol, F. A., Norhayate, W., Daud, W., Rashid, N., \& Afthanorhan, A. (2018). Application of Entrepreneurial Marketing to the Marketing Mix : Why it Matters to SMEs in Malaysia ? Application of Entrepreneurial Marketing to the Marketing Mix : Why it Matters to SMEs in Malaysia ? International Journal of Academic Research in Business and Social Sciences, 8(12), 850-865. http://doi.org/10.6007/IJARBSS/v8-i12/5079

Ismail, S. A., Ghazali, P. L., Baharazi, N. Z., Amran, N. A., Salleh, F., Omar, L. Bin, ... Rashid, N. (2016). Application of integration model for recovery fund in takaful education plan. Far East Journal of Mathematical Sciences, 100(2), 301-313. http://doi.org/10.17654/MS100020301

Johari, R. J., Rashid, N., \& Yazid, A. S. (2018). An Empirical Examination of Undergraduate Accounting Students ' Ethical Judgment : Malaysia Evidence An Empirical Examination of Undergraduate Accounting Students ' Ethical Judgment : Malaysia Evidence. International Journal of Academic Research in Business and Social Sciences, 8(12), 669-681. http://doi.org/10.6007/IJARBSS/v8-i12/5064

Johari, R. J., Tarmizi, M., Mohd, H., \& Rashid, N. (2018). A Revisited Note on Internal Audit Function and Good Corporate Governance A Revisited Note on Internal Audit Function and Good Corporate Governance. International Journal of Academic Research in Business and Social Sciences, 8(12), 716-728. http://doi.org/10.6007/IJARBSS/v8-i12/5067

Kraft, A., Lee, B. S., \& Lopatta, K. (2014). Management earnings forecasts, insider trading, and information asymmetry. Journal of Corporate Finance, 26, 96-123. http://doi.org/10.1016/j.jcorpfin.2014.03.002

Kurniasih, C. E., Nasir, M., Mahmud, M. S., Rashid, N., Ghazali, P. L., \& Afthanorhan, A. (2018). Analysis of the Relationship between World Oil Price and Exchange Rate on Agricultural Commodity Prices in Indonesia Analysis of the Relationship between World Oil Price and Exchange Rate on Agricultural Commodity Prices in Indonesia. International Journal of Academic Research in Business and Social Sciences, 8(12), 561-576. http://doi.org/10.6007/IJARBSS/v8-i12/5055

Mahmod, M. S., Aziz, K., Yazid, A. S., Rashid, N., Salleh, F., \& Ghazali, P. L. (2018). A Conceptual Framework of ERM Practices among SMEs IN Malaysia A Conceptual Framework of ERM Practices among SMEs IN Malaysia. International Journal of Academic Research in Business and Social Sciences, 8(11), 1209-1221. http://doi.org/10.6007/IJARBSS/v8-i11/5163

Noor, N., Norhayate, W., Rashid, N., \& Asyraf, A. (2018). Exploring the Predominant Qualities of 
INTERNATIONAL JOURNAL OF ACADEMIC RESEARCH IN BUSINESS AND SOCIAL SCIENCES

Vol. 8, No. 11, Nov, 2018, E-ISSN: 2222-6990 @ 2018 HRMARS

Head Teachers towards Achieving School Success Exploring the Predominant Qualities of Head Teachers towards Achieving School Success. International Journal of Academic Research in Business and Social Sciences, 8(11), 1324-1330. http://doi.org/10.6007/IJARBSS/v8-i11/5173

Norliana, A. M., Fakhrul Anwar, Z., Wan Norhayate, W. D., Norfadzilah, R., \& Asyraf, A. (2018). Entrepreneurial Intention from the Islamic Perspective : A Holistic Approach Entrepreneurial Intention from the Islamic Perspective : A Holistic Approach. International Journal of Academic Research in Business and Social Sciences, 8(12), 820-833. http://doi.org/10.6007/IJARBSS/v8i12/5077

Otusanya, O. J. (2011). The role of multinational companies in tax evasion and tax avoidance: The case of Nigeria. Critical Perspectives on Accounting, 22(3), 316-332. http://doi.org/10.1016/j.cpa.2010.10.005

Rashid, N., Fara, N., Kamal, S., Hamid, N. A., Ghazali, N., Yusop, R., ... Abd, N. (2018). The Effect of Government Support Programs and Compliance Costs on Goods and Services Tax Compliance among Malaysian Batik Manufacturers The Effect of Government Support Programs and Compliance Costs on Goods and Services Tax Compliance among Malaysian Bat. International Journal of Academic Research in Business and Social Sciences, 8(12), 682-694. http://doi.org/10.6007/IJARBSS/v8-i12/5065

Rashid, N., Muhmad, S. N., Hassan, M., Haat, C., Muhmad, S. N., Hashim, H. A., \& Afthanorhan, A. (2018). Risk Management Effectiveness Index Score for Pre and Post Malaysian Code on Corporate Governance 2012 Risk Management Effectiveness Index Score for Pre and Post Malaysian Code on Corporate Governance. International Journal of Academic Research in Business and Social Sciences, 8(12), 729-741. http://doi.org/10.6007/IJARBSS/v8-i12/5068

Sabiu, I. T., Zainol, F. A., Norhayate, W., Daud, W., Rashid, N., Afthanorhan, A., ... Zainol, F. A. (2018). Big Five Personality Characteristics : An Exploratory Study on Bumiputra SMEs in Malaysia Big Five Personality Characteristics : An Exploratory Study on Bumiputra SMEs in Malaysia. International Journal of Academic Research in Business and Social Sciences, 8(12), 866-881. http://doi.org/10.6007/IJARBSS/v8-i12/5080

Salleh, F., Ibrahim, M. D., Yazid, A. S., Afthanorhan, A., Rashid, N., \& Ghazali, P. L. (2018). Micro Small and Medium Enterprise Demand for General Takaful : Proposed Theoretical Framework and Hypotheses Development Micro Small and Medium Enterprise Demand for General Takaful : Proposed Theoretical Framework and Hypotheses Development. International Journal of Academic Research in Business and Social Sciences, 8(12), 599-612. http://doi.org/10.6007/IJARBSS/v8-i12/5058

Salleh, F., Noor, D., Ag, H., Yazid, A. S., Salleh, F., Noor, D., ... Rashid, N. (2018). Consumer Behaviour and Insurance Claim Fraud in Malaysia Consumer Behaviour and Insurance Claim Fraud in Malaysia. International Journal of Academic Research in Business and Social Sciences, 8(12), 586-598. http://doi.org/10.6007/IJARBSS/v8-i12/5057

Sambharya, R. B. (2011). Security analysts' earnings forecasts as a measure of firm performance: An empirical exploration of its domain. Management Decision, 49(7), 1160-1181. http://doi.org/10.1108/00251741111151190

Usop, R., Zainol, F. A., Chik, Z., Norhayate, W., Daud, W., Rashid, N., \& Afthanorhan, A. (2018). Competitive Advantage and Performance : Empirical Investigation on Demographic Factors of 
Malaysian Hotel Entrepreneurs Competitive Advantage and Performance : Empirical Investigation on Demographic Factors of Malaysian Hotel Entrepreneurs. International Journal of Academic Research in Business and Social Sciences, 8(12), 810-819. http://doi.org/10.6007/IJARBSS/v8-i12/5067

Zain, F. A. M., Abdullah, W. A. W., \& Rashid, N. (2018). The Mediating Role of Environmental Performance on The Relationship Between Corporate Governance Mechanisms and Environmental Disclosure. Asian Academy of Management Journal of Accounting and Finance, 14(1), 153-183. http://doi.org/10.21315/aamjaf2018.14.1.7

Zainol, F. A., Aik, C. K., Muthmainnah, N., Hadi, H., Norhayate, W., Daud, W., ... Muthmainnah, N. (2018). Food Security and Food Value Chain : Identifying the Influencing Components in Malaysian Seed Industry Food Security and Food Value Chain : Identifying the Influencing Components in Malaysian Seed Industry. International Journal of Academic Research in Business and Social Sciences, 8(12), 834-849. http://doi.org/10.6007/IJARBSS/v8-i12/5078 